\title{
Review
}

\section{Histamine: A Bacterial Signal Molecule}

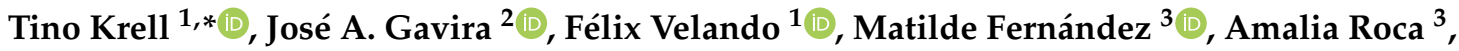 \\ Elizabet Monteagudo-Cascales ${ }^{1}$ and Miguel A. Matilla ${ }^{1, *(1)}$
}

1 Department of Environmental Protection, Estación Experimental del Zaidín, Consejo Superior de Investigaciones Científicas, Prof. Albareda 1, 18008 Granada, Spain; felix.velando@eez.csic.es (F.V.); elizabet.monteagudo@eez.csic.es (E.M.-C.)

2 Laboratory of Crystallographic Studies, IACT (CSIC-UGR), Avenida de las Palmeras 4, 18100 Armilla, Spain; jgavira@iact.ugr-csic.es

3 Department of Microbiology, Facultad de Farmacia, Campus Universitario de Cartuja, Universidad de Granada, 18071 Granada, Spain; matildefernandez@ugr.es (M.F.); amaliaroca@ugr.es (A.R.)

* Correspondence: tino.krell@eez.csic.es (T.K.); miguel.matilla@eez.csic.es (M.A.M.); Tel.: +34-958-181600 (T.K.); +34-958-181600 (M.A.M.); Fax: +34-958-135740 (T.K.); +34-958-135740 (M.A.M.)

check for

updates

Citation: Krell, T.; Gavira, J.A.; Velando, F.; Fernández, M.; Roca, A.; Monteagudo-Cascales, E.; Matilla, M.A. Histamine: A Bacterial Signal Molecule. Int. J. Mol. Sci. 2021, 22, 6312. https://doi.org/10.3390/ ijms22126312

\section{Academic Editors:}

Katharina Kubatzky and Elisabeth Seebach

Received: 1 June 2021

Accepted: 10 June 2021

Published: 12 June 2021

Publisher's Note: MDPI stays neutral with regard to jurisdictional claims in published maps and institutional affiliations.

Copyright: (c) 2021 by the authors. Licensee MDPI, Basel, Switzerland. This article is an open access article distributed under the terms and conditions of the Creative Commons Attribution (CC BY) license (https:/ / creativecommons.org/licenses/by/ $4.0 /)$.

\begin{abstract}
Bacteria have evolved sophisticated signaling mechanisms to coordinate interactions with organisms of other domains, such as plants, animals and human hosts. Several important signal molecules have been identified that are synthesized by members of different domains and that play important roles in inter-domain communication. In this article, we review recent data supporting that histamine is a signal molecule that may play an important role in inter-domain and inter-species communication. Histamine is a key signal molecule in humans, with multiple functions, such as being a neurotransmitter or modulator of immune responses. More recent studies have shown that bacteria have evolved different mechanisms to sense histamine or histamine metabolites. Histamine sensing in the human pathogen Pseudomonas aeruginosa was found to trigger chemoattraction to histamine and to regulate the expression of many virulence-related genes. Further studies have shown that many bacteria are able to synthesize and secrete histamine. The release of histamine by bacteria in the human gut was found to modulate the host immune responses and, at higher doses, to result in host pathologies. The elucidation of the role of histamine as an inter-domain signaling molecule is an emerging field of research and future investigation is required to assess its potential general nature.
\end{abstract}

Keywords: histamine; signal molecule; sensing; Pseudomonas aeruginosa; histamine receptors; chemotaxis; gut microbiome

\section{Introduction}

Bacteria have evolved a large number of signal transduction systems that recognize different signals and generate, in return, adaptive responses. Major protein families include transcriptional regulators, two-component systems (TCS), chemoreceptors, proteins involved in the synthesis and hydrolysis of the c-di-GMP and c-di-AMP second messengers, extracytoplasmic function (ECF) sigma factors and Ser/Thr/Tyr kinases [1]. Stimuli recognized are diverse and include an enormous variety of low molecular weight compounds, $\mathrm{pH}$, temperature, light or osmotic stress, among others [2,3]. Major forms of signaling responses are transcriptional regulation, chemotactic movements or alterations in second messenger levels [1].

Frequently, bacteria establish interactions with organisms of other domains like animals, humans or plants. These interactions can either be of mutual benefit or part of a virulence strategy. A number of central signal molecules have been described that are synthesized and secreted by the bacterium as well as by its host. These signal molecules mediate intra- and inter-species communication that regulates multiple metabolic and physiological processes in both bacteria and their hosts [4,5]. The investigation of the role 
of these central signal molecules in the inter-domain crosstalk is a rapidly expanding field of research. A representative example for such central inter-species signals is the auxin indole-3-acetic acid (IAA) that is a key plant hormone, regulating, among other processes, plant growth and development [6]. However, IAA is commonly produced and secreted by bacteria that interact with plants and plays a key role in mediating plant-bacteria interactions $[7,8]$. Another example is the crosstalk that exists between the human gastrointestinal hormones, epinephrine and noradrenaline, and bacterial autoinducers to modulate bacterial physiology and metabolism, as well as the host's inflammatory responses [9].

There is now emerging evidence, reviewed in this article, that histamine may be another central signal molecule that mediates bacteria-host interactions. Histamine is primarily known for its central role it plays in humans. It is a human neurotransmitter, a modulator of inflammatory reactions and the immune response and a key mediator of several events in allergies and autoimmune diseases [10]. Further activities of histamine include a participation in cell proliferation, differentiation, hematopoiesis, embryonic development, secretion of pituitary hormones as well as a regulation of gastrointestinal, cardiovascular and circulatory functions [11]. Histamine is synthesized from L-histidine by histidine decarboxylase (HDC). It is primarily secreted by mast cells and basophiles, and it exerts its function through four different types of histamine receptors, termed H1R, H2R, H3R and H4R [11].

A wide range of Gram-positive and Gram-negative bacteria were found to possess HDC-encoding genes and to synthesize histamine [12]. There appear to be two bacterial HDC superfamilies, namely those that require pyridoxal phosphate as a coenzyme, found primarily in Gram-negative bacteria, and those in Gram-positive species that employ a covalently bound pyruvate moiety for catalysis [12]. The regulation of the expression of $h d c$ genes has been studied in several bacteria. Histidine was found to induce the expression of $h d c$ genes [13-16], whereas histamine slightly repressed its expression in several lactic bacteria belonging to the Lactobacillus, Pediococcus and Oenococcus genera [14].

Apart from their capacity to synthesize histamine, more recent studies have shown that some bacteria are able to metabolize histamine. Pseudomonas species are characterized by an enormous metabolic versatility [17], and de la Torre et al. revealed that P. putida $\mathrm{U}$ is able to grow aerobically in a minimal medium, containing histamine as the sole carbon source [18]. The degradation of histamine coincided with the appearance of imidazole4 -acetic acid (ImAA), suggesting that the latter compound is a major intermediate in the degradation route. The authors showed that 11 proteins (HinABCDFLHGIJK), encoded in four different genomic regions (clusters hin 1 (hinABCD), hin2 (hinFLHG) and hin3 (hinIJ) and the stand-alone hinK gene), are required for histamine degradation in P. putida $\mathrm{U}$ [18]. Of these proteins, one is a histidine permease (HinA), three are transcriptional regulators (HinB, HinJ and HinK) and the remaining proteins are catabolic enzymes. A six-step catabolic process converts histamine into aspartic acid that is then converted into the tricarboxylic acid (TCA) cycle intermediate, fumaric acid [18]. To determine to which extent other bacteria may be able to degrade histamine, the authors inspected genomes for the presence of hin genes. These genes were commonly present in strains of the genus Pseudomonas but absent from any of the as-yet sequenced Gram-positive bacteria [18].

The detection of signal molecules by bacteria can serve several purposes: (i) they can indicate the presence of a compound of metabolic value or toxicity, or (ii) they can inform the bacterium of its present environmental niche. For a number of signal molecules, the physiological purposes of sensing appear to be tightly interwoven and include the metabolic aspect as well as the aspect of gaining information on the ecological niche. Histamine may be one of these signals. Bacterial histamine signaling is an emerging field of research that is reviewed here. In the first part of this article, we reviewed studies illustrating the histamine sensing capacity of bacteria, whereas we focused attention, in the second part, on the consequences of bacterial histamine secretion on the host. 


\section{Histamine Sensing by Bacteria}

\subsection{Pseudomonas aeruginosa PAO1}

P. aeruginosa is among the most feared human pathogens. It is an opportunistic pathogen that infects virtually any tissue [19] and is the leading cause of nosocomial infections, particularly in immunocompromised, cancer, burn-wound and cystic fibrosis patients [20] and a frequent cause of bacteremia [21]. The World Health Organization (WHO) has placed P. aeruginosa second on the global priority list of antibiotic-resistant bacteria to guide research, discovery and development of new antibiotics and has rated the development of new antimicrobial agents against P. aeruginosa as critical [22]. Strain PAO1 was found to be able to grow on histamine as a sole carbon and nitrogen source, indicating that it harbors a functional histamine degradation pathway [23]. In a subsequent study, it was found that the histamine catabolic pathway described in the non-pathogenic P. putida $\mathrm{U}$ [18] is also highly conserved in the opportunistic human pathogen Pseudomonas aeruginosa (Figure 1) [24].

A

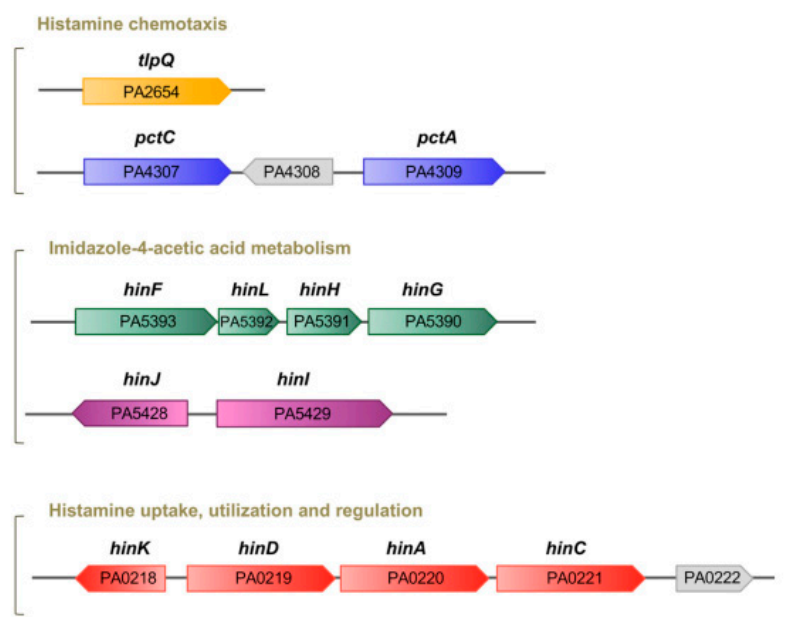

B
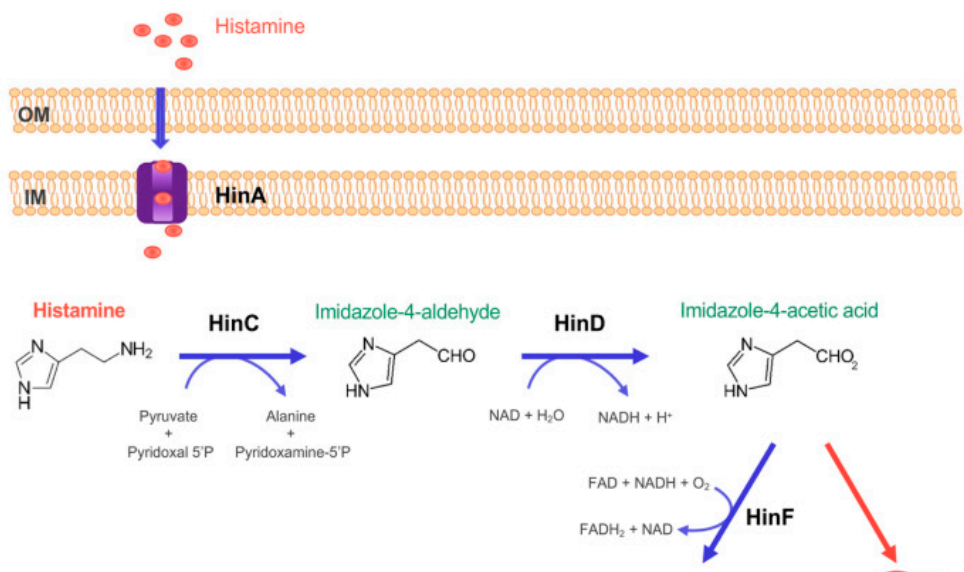

nidazole-4-acetic acid

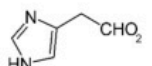

4-imidazolone-5-acetic acid

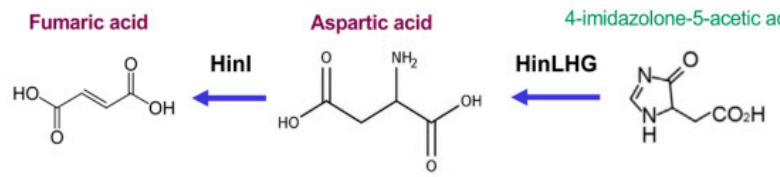

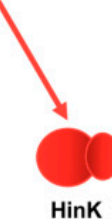

HinK

Figure 1. Genes and proteins involved in histamine metabolism, transport, regulation and chemotaxis in P. aeruginosa PAO1. (A) Genetic organization of genes. (B) The proposed histamine catabolic pathway. Data are based on [18,23,24].

\subsubsection{Transcriptional Responses to Histamine Exposure}

The effect of histamine on bacterial gene transcript levels was assessed, for the first time, using P. aeruginosa PAO1 as a model system [24], the primary reference strain for this pathogen. RNA-seq experiments were conducted, comparing the wild-type (wt) strain in the absence and presence of $2 \mathrm{mM}$ histamine, and samples were taken $3 \mathrm{~h}$ after histamine addition. This study showed that the transcript levels of approximately $8.5 \%$ of the PAO1 genes showed at least a three-fold change. There were, in total, 301 upregulated and 178 downregulated genes, a selection of which is shown in Table 1.

The authors selected nine genes and determined histamine-induced changes in transcript levels using quantitative real-time PCR (RT-qPCR), and the results obtained were consistent with RNA-seq data. Furthermore, additional RT-qPCR studies showed significant changes in the transcript levels of the hinD, hinF, pvdS and pqs A genes at a 1000-fold lower histamine concentration $(2 \mu \mathrm{M})$, indicative of high-affinity signal recognition [24]. 
Table 1. The effect of histamine on P. aeruginosa PAO1 transcript levels. Shown is a selection of genes with altered transcript levels in an RNA-seq study comparing the wt strain in the absence and presence of $2 \mathrm{mM}$ histamine. Many of these genes play a role in virulence. In total, approximately $8.5 \%$ of the $P$. aeruginosa genes showed at least a three-fold change. Data were taken from [24].

\begin{tabular}{|c|c|c|c|c|c|}
\hline Gene ID & Name & $\begin{array}{l}\log _{2} \text { Fold } \\
\text { Change }\end{array}$ & Description & $\begin{array}{l}\text { Function/ } \\
\text { Comment }\end{array}$ & $\begin{array}{c}\text { Ref. } \\
\text { Function }\end{array}$ \\
\hline \multicolumn{6}{|c|}{ Histamine-mediated upregulation } \\
\hline \multicolumn{6}{|c|}{ Histamine metabolism, transport and regulation } \\
\hline PA5390 & $\operatorname{hin} G$ & 7.9 & Probable peptidic bond hydrolase & \multirow{6}{*}{ Histamine utilization } & \multirow{9}{*}{ [24] } \\
\hline PA5391 & $\operatorname{hin} H$ & 10.9 & Hypothetical protein & & \\
\hline PA5392 & $\operatorname{hinL}$ & 10.7 & Conserved hypothetical protein & & \\
\hline PA5393 & $\operatorname{hinF}$ & 11.1 & Conserved hypothetical protein & & \\
\hline PA0219 & $\operatorname{hin} D$ & 10.0 & Probable aldehyde dehydrogenase & & \\
\hline PA0221 & $\operatorname{hin} C$ & 10.0 & Probable aminotransferase & & \\
\hline PA0220 & $\operatorname{hin} A$ & 9.5 & Histamine transporter & Histamine transport & \\
\hline PA0218 & $\operatorname{hin} K$ & 4.8 & Transcriptional regulator & $\begin{array}{l}\text { Histamine-mediated } \\
\text { regulation }\end{array}$ & \\
\hline PA0222 & & 8.7 & Solute-binding protein & Possibly transport & \\
\hline \multicolumn{6}{|c|}{ Iron acquisition } \\
\hline PA0931 & pirA & 3.2 & Ferric enterobactin receptor PirA & \multirow{17}{*}{$\begin{array}{l}\text { Siderophore pyoverdin } \\
\text { synthesis, secretion, } \\
\text { regulation and } \\
\text { pyoverdin-Fe uptake }\end{array}$} & [25] \\
\hline PA2385 & $p v d Q$ & 6.3 & $\begin{array}{l}\text { 3-oxo-C12-homoserine lactone } \\
\text { acylase PvdQ }\end{array}$ & & \multirow{16}{*}{ [26] } \\
\hline PA2386 & $p v d A$ & 7.5 & L-ornithine N5-oxygenase & & \\
\hline PA2389 & $p v d R$ & 2.6 & PvdR & & \\
\hline PA2390 & $p v d T$ & 2.4 & PvdT & & \\
\hline PA2392 & $p v d P$ & 4.1 & PvdP & & \\
\hline PA2394 & $\operatorname{pvdN}$ & 5.9 & PvdN & & \\
\hline PA2395 & pvdO & 6.3 & PvdO & & \\
\hline PA2396 & $p v d F$ & 3.4 & Pyoverdine synthetase F & & \\
\hline PA2397 & $p v d E$ & 6.3 & Pyoverdine biosynthesis protein PvdE & & \\
\hline PA2398 & $f p v A$ & 6.0 & Ferripyoverdine receptor & & \\
\hline PA2399 & $p v d D$ & 2.9 & Pyoverdine synthetase D & & \\
\hline PA2400 & pvdJ & 3.0 & PvdJ & & \\
\hline PA2413 & $p v d H$ & 5.6 & $\begin{array}{l}\text { L-2,4-diaminobutyrate:2-ketoglutarate } \\
\text { 4-aminotransferase }\end{array}$ & & \\
\hline PA2424 & $p v d L$ & 5.8 & PvdL & & \\
\hline PA2425 & $p v d G$ & 6.2 & PvdG & & \\
\hline PA2426 & $p v d S$ & 5.7 & Sigma factor PvdS & & \\
\hline PA0472 & fiuI & 3.1 & ECF sigma factor FiuI & Ferrichrome activated & [27] \\
\hline PA2468 & foxI & 2.5 & ECF sigma factor FoxI & Ferrioxamine activated & [28] \\
\hline PA3410 & hasI & 2.9 & ECF sigma factor HasI & Heme activated & [29] \\
\hline PA4168 & $f p v B$ & 3.3 & Second ferric pyoverdine receptor FpvB & Pyoverdine transport & [30] \\
\hline
\end{tabular}


Table 1. Cont.

\begin{tabular}{|c|c|c|c|c|c|}
\hline Gene ID & Name & $\begin{array}{l}\log _{2} \text { Fold } \\
\text { Change }\end{array}$ & Description & $\begin{array}{l}\text { Function/ } \\
\text { Comment }\end{array}$ & $\begin{array}{c}\text { Ref. } \\
\text { Function }\end{array}$ \\
\hline PA4221 & fptA & 1.7 & $\begin{array}{l}\text { Fe(III)-pyochelin outer membrane } \\
\text { receptor precursor }\end{array}$ & \multirow{6}{*}{$\begin{array}{l}\text { Siderophore pyochelin } \\
\text { synthesis and transport }\end{array}$} & \multirow{6}{*}{ [31] } \\
\hline PA4226 & pchE & 3.1 & Dihydroaeruginoic acid synthetase & & \\
\hline PA4228 & $p c h D$ & 4.1 & Pyochelin biosynthesis protein PchD & & \\
\hline PA4229 & $p \operatorname{chC}$ & 3.6 & Pyochelin biosynthetic protein PchC & & \\
\hline PA4230 & $p c h B$ & 2.7 & Salicylate biosynthesis protein PchB & & \\
\hline PA4231 & $\operatorname{pch} A$ & 2.3 & $\begin{array}{l}\text { Salicylate biosynthesis } \\
\text { isochorismate synthase }\end{array}$ & & \\
\hline PA4687 & hitA & 3.3 & $\begin{array}{l}\text { Ferric iron-binding periplasmic } \\
\text { protein HitA }\end{array}$ & \multirow{2}{*}{ Iron transport } & \multirow{2}{*}{ [32] } \\
\hline PA4688 & hitB & 3.2 & $\begin{array}{l}\text { Iron (III)-transport system } \\
\text { permease HitB }\end{array}$ & & \\
\hline & & & Quorum sensing & & \\
\hline PA0996 & $p q s A$ & 3.4 & Probable coenzyme A ligase & \multirow{5}{*}{$\begin{array}{l}\text { Pseudomonas quinolone } \\
\text { signal (PQS) quorum } \\
\text { sensing system }\end{array}$} & \multirow{5}{*}{ [33] } \\
\hline PA0997 & $p q s B$ & 3.8 & PqsB & & \\
\hline PA0998 & $p q s C$ & 3.8 & PqsC & & \\
\hline PA0999 & $p q s D$ & 3.8 & $\begin{array}{l}\text { 3-oxoacyl-[acyl-carrier-protein] } \\
\text { synthase III }\end{array}$ & & \\
\hline PA1000 & $p q s E$ & 3.6 & Quinolone signal response protein & & \\
\hline PA1001 & phnA & 3.5 & \multirow{2}{*}{$\begin{array}{l}\text { Anthranilate synthase components I and } \\
\text { II (important for PQS synthesis) }\end{array}$} & \multirow{2}{*}{ PQS synthesis } & \multirow{2}{*}[34]{} \\
\hline PA1002 & phnB & 3.0 & & & \\
\hline \multicolumn{6}{|c|}{ Secretion system } \\
\hline PA1718 & pscE & 2.3 & Type III export protein PscE & \multirow{3}{*}{$\begin{array}{l}\text { Type III secretion } \\
\text { apparatus }\end{array}$} & \multirow{3}{*}{ [35] } \\
\hline PA1721 & pscH & 1.9 & Type III export protein PscH & & \\
\hline PA1715 & $p s c B$ & 1.8 & Type III export apparatus protein & & \\
\hline \multicolumn{6}{|c|}{ Regulation } \\
\hline PA0707 & toxR & 1.9 & Transcriptional regulator ToxR & Exotoxin A expression & [36] \\
\hline PA0612 & $\operatorname{ptr} B$ & 2.0 & Repressor PtrB & $\begin{array}{c}\text { Type III secretion system } \\
\text { expression }\end{array}$ & [37] \\
\hline PA1431 & $r s a L$ & 2.0 & Regulatory protein RsaL & $\begin{array}{l}\text { Virulence and biofilm } \\
\text { formation }\end{array}$ & [38] \\
\hline PA2227 & $v q s M$ & 2.4 & Transcriptional regulator VqsM & $\begin{array}{l}\text { Quorum sensing and } \\
\text { virulence }\end{array}$ & [39] \\
\hline PA2686 & $p f e R$ & 3.1 & PfeR response regulator & \multirow{2}{*}{ Enterobactin receptor } & \multirow{2}{*}{ [40] } \\
\hline PA2687 & pfes & 2.6 & PfeS sensor kinase & & \\
\hline PA3006 & psra & 1.8 & Transcriptional regulator PsrA & Type III secretion system & [41] \\
\hline PA4315 & mvaT & 2.3 & Transcriptional regulator MvaT & Type III secretion system & [42] \\
\hline PA5124 & $n \operatorname{tr} B$ & 4.0 & NtrB kinase & \multirow{2}{*}{$\begin{array}{l}\text { Invasiveness and } \\
\text { Virulence }\end{array}$} & \multirow{2}{*}{ [43] } \\
\hline PA5125 & $n t r C$ & 3.7 & NtrC response regulator & & \\
\hline \multicolumn{6}{|c|}{ Others } \\
\hline PA4760 & dnaJ & 3.2 & Heat shock protein & Pyocyanin production & [44] \\
\hline PA4761 & $d n a K$ & 3.7 & Chaperone DnaK & $\begin{array}{l}\text { Translocation across the } \\
\text { intestinal epithelia cells }\end{array}$ & [45] \\
\hline
\end{tabular}


Table 1. Cont

\begin{tabular}{|c|c|c|c|c|c|}
\hline Gene ID & Name & $\begin{array}{l}\log _{2} \text { Fold } \\
\text { Change }\end{array}$ & Description & $\begin{array}{l}\text { Function/ } \\
\text { Comment }\end{array}$ & $\begin{array}{c}\text { Ref. } \\
\text { Function }\end{array}$ \\
\hline \multicolumn{6}{|c|}{ Histamine-mediated downregulation } \\
\hline \multicolumn{6}{|c|}{ Regulation } \\
\hline PA0173 & cheB2 & -2.1 & $\mathrm{CheB}_{2}$ methylesterase & \multirow{5}{*}{$\begin{array}{c}\text { Che2 pathway, unknown } \\
\text { function, involved in } \\
\text { virulence }\end{array}$} & \multirow{5}{*}[46,47]{} \\
\hline PA0174 & cheD & -2.2 & CheD deamidase & & \\
\hline PA0175 & cheR2 & -2.4 & CheR2 methyltransferase & & \\
\hline PA0176 & $m c p B / a e r 2$ & -2.3 & Aer2/McpB chemoreceptor & & \\
\hline PA0177 & cheW & -1.9 & CheW coupling protein & & \\
\hline PA4293 & pprA & -2.5 & Sensor kinase PprA & \multirow{2}{*}{$\begin{array}{c}\text { Quorum } \\
\text { sensingregulation }\end{array}$} & \multirow{2}{*}{ [48] } \\
\hline PA4296 & pprB & -1.6 & Response regulator PprB & & \\
\hline \multicolumn{6}{|c|}{ Motility } \\
\hline PA1930 & $m c p S$ & -2.1 & Chemoreceptor McpS & Chemotaxis & {$[49]$} \\
\hline PA2561 & $c t p H$ & -2.4 & $\begin{array}{l}\text { Inorganic phosphate }(\mathrm{Pi}) \text { specific } \\
\text { chemoreceptor } \mathrm{CtpH}\end{array}$ & $\begin{array}{c}\text { Pi is a major virulence } \\
\text { signal }\end{array}$ & {$[50,51]$} \\
\hline \multicolumn{6}{|c|}{ Others } \\
\hline PA4299-4306 & $\begin{array}{l}\text { Flp-tad- } \\
\text { rcp } \\
\text { locus }\end{array}$ & -2.3 to -4.8 & Formation of type IVb pili & $\begin{array}{l}\text { Aggregation and biofilm } \\
\text { formation }\end{array}$ & [52] \\
\hline PA4236 & kat $A$ & -2.1 & Major catalase KatA & $\begin{array}{l}\text { Osmoprotection and } \\
\text { virulence }\end{array}$ & [53] \\
\hline
\end{tabular}

Histamine exposure caused significant changes in histamine-related genes, such as genes encoding enzymes for histamine metabolism (HinCDFLHG), transport (HinA) and regulation (HinK) (Table 1, Figure 1).

Of note are the large changes that have been observed for the genes involved in histamine metabolism that ranged from a 240- to 2200-fold increase in the presence of histamine [24]. Many of the identified histamine-regulated genes were either directly or indirectly related to different virulence processes (Table 1). A large number of the upregulated genes were associated with iron uptake, such as those encoding proteins for the synthesis and secretion of the pyoverdin and pyochelin siderophores, iron transport or different ECF sigma factors (Table 1). Further upregulated genes encoded proteins involved in the synthesis of the Pseudomonas quinolone quorum sensing signal (PQS) or the type III secretion system. Another group of upregulated genes had regulatory functions, such as the transcriptional regulators ToxR, PtrB, MvaT, VqsM, PsrA and RsaL (Table 1) that regulate diverse processes, such as the expression of genes encoding the primary toxin endotoxin A [36], quorum sensing proteins [39] or the type III secretion system [41]. Alternatively, several of the downregulated genes also had regulatory functions (Table 1) [24], such as components of the Che 2 chemosensory pathway, which is of unknown function but related to virulence [46,47], or the quorum-sensing PprAB two-component system [48]. In addition, two chemotaxis chemoreceptors were downregulated, including $\mathrm{CtpH}$, a chemoreceptor specific for inorganic phosphate, a major signal regulating P. aeruginosa virulence [51].

2.1.2. A Large Part of Histamine-Dependent Transcriptional Responses Are Mediated by the Transcriptional Regulator HinK

Among the genes that were upregulated in the presence of histamine was hinK, encoding a LysR-type transcriptional regulator. HinK was first identified in P. putida $\mathrm{U}$, and it regulates histamine catabolism in this strain, together with the transcriptional regulators HinB and HinJ, as described above [18]. In PAO1, the hinK gene was found to be next to 
the hinDAC genes that were involved in histamine metabolism and transport (Figure 1). To assess the role of HinK in the histidine-mediated regulation, the authors conducted RNA-seq experiments, comparing the wt with the hinK mutant in the presence of histamine, showing a significantly changed pattern in the gene transcript levels with respect to the experiment comparing the histamine-free and -supplemented wt strain [24]. To verify whether HinK controls the expression of the hinDAC genes, the authors constructed a hinD promoter-lux transcriptional fusion. In the wt strain, the addition of histamine caused an important increase in the transcriptional activity, whereas no changes were observed in the hinK mutant, a phenotype reversed by mutant complementation [24]. Analogous experiments showed that HinK also regulates the transcription of the hinFLHG operon (Figure 1) as well as its own expression [24]. Electrophoretic mobility shifts revealed that HinK binds to the hinD and hinF promoters, and a conserved sequence motif in both promoters was identified as the HinK operator site [24].

HinK is composed of a DNA binding- and ligand-binding domain (LBD), and experiments were conducted to identify the signal that binds and activates HinK. Several pieces of evidence indicate that HinK does not recognize histamine directly but instead imidazole-4-acetic acid (ImAA), which corresponds to an intermediate in the metabolic pathway converting histamine into aspartic acid, as described above (Figure 1B). Electrophoretic mobility shift assays revealed that micromolar concentrations of ImAA caused HinK binding at its target DNA, namely hinD and hinF promoters, an observation that was not made using a variety of related compounds, including histamine [24]. These data are not fully consistent with the relatively low affinity, of $1.56 \mathrm{mM}$, for the binding of ImAA to HinK [24]. The authors reported the three-dimensional structure of the apo HinK protein and ImAA binding studies to site-directed HinK mutants indicate that the ligand binds between both lobes of the LBD in a manner similar to other LysR type transcriptional regulators [24].

\subsubsection{HinA Is a Histamine Transporter Permitting Histamine Uptake and Sensing by HinK}

HinA is an APC (amino-acid-polyamine-organocation)-type transporter, and several pieces of evidence indicate that it is the primary histamine transporter. In P. putida $\mathrm{U}$, a mutant in the $\operatorname{hin} A$ gene was unable to take up tritium-labelled histamine, a phenotype that was reversed by complementation with the hinA gene [18]. Wang et al. refered to P. aeruginosa PA0220 as the HinA homologue [24]; however, the sequence identity between both proteins, with $17 \%$, is very modest. They showed that the deletion of P. aeruginosa hinA significantly reduced the transcriptional activity from the hinD promoter that was found to be controlled by HinK in response to histamine, which supports the notion that HinA is the primary histamine transporter. Transporters often employ extracytosolic solute binding proteins that present the transport substrate to the permease [54]. In close vicinity to the hinA gene is a gene encoding a solute-binding protein, PA0222 (Figure 1A), and histamine was found to increase its transcript levels by 400 -fold (Table 1). However, microcalorimetric titrations of purified PA0222 showed that it bound $\gamma$-aminobutyrate with nanomolar affinity but failed to recognize histamine [55]. The potential role of PA0222 in histamine transport is thus unclear.

\subsubsection{Histamine and HinK Regulate P. aeruginosa Virulence}

Based on the observation that histamine induces the expression of many virulencerelated genes, Wang et al. conducted experiments to elucidate, in more detail, the role of histamine in P. aeruginosa virulence [24]. Using the Drosophila melanogaster model, the authors showed that histamine treatment increased bacterial virulence, whereas no change in virulence was noted for the hinK mutant, a phenotype that was reversed by complementation with hinK. The same strains were analyzed in a mouse acute lung infection model. In accordance with the above data, the deletion of hinK caused a significant reduction in virulence as compared to the $\mathrm{wt}$ and the complemented mutant strain [24]. The data thus indicate that histamine is a signal molecule that regulates $P$. aeruginosa virulence. 


\subsubsection{Histamine Chemotaxis}

P. aeruginosa PAO1 and P. putida KT2440 were found to move chemotactically to histamine [23]. The onset of chemotaxis occurred for P. aeruginosa at the unusually low concentration of $500 \mathrm{nM}$, whereas initial responses of P. putida were observed at $5 \mu \mathrm{M}$. Over the entire histamine concentration range tested, i.e., $500 \mathrm{nM}$ to $50 \mathrm{mM}$, the magnitude of chemotaxis of PAO1 was well superior to that of KT2440 [23]. Maximal responses of PAO1 were detected at $5 \mathrm{mM}$. Strain PAO1 has 26 chemoreceptors, of which 23 were predicted to stimulate the chemotaxis pathway $[46,56]$. Experimentation with a number of chemoreceptor mutants revealed that the histamine chemotaxis was not based on a single chemoreceptor, like for many other chemoeffectors studied, but on the concerted action of the TlpQ, PctA and PctC chemoreceptors [23]. Interestingly, mutants in $p c t A$ and $p c t C$ failed to respond to a high histamine concentration (i.e., 5-50 mM), whereas the $t l p Q$ mutant did not respond to low concentrations (i.e., $500 \mathrm{nM}-500 \mu \mathrm{M}$ ) [23]. Therefore, the combined action of three chemoreceptors with different sensitivities broadened the response range, a finding reminiscent of the action of the $\mathrm{CtpL}$ and $\mathrm{CtpH}$ chemoreceptors for inorganic phosphate [50,57]. Like histamine, inorganic phosphate is of central physiological relevance, since it is a key signal that regulates the expression of many virulence-related genes [51,58]. It is tempting to speculate that the recognition of a specific signal molecule by multiple chemoreceptors reflects a particular physiological relevance of the signal. PctA and PctC have previously been shown to bind and mediate chemoattraction to different proteinogenic amino acids and $\gamma$-aminobutyrate [59-61]. Both receptors possess a dCache type LBD [62] that binds proteinogenic amino acids and $\gamma$-aminobutyrate directly $[59,60]$. However, microcalorimetric titrations of the individual PctA and PctC LBDs with histamine did not show binding [23]. It was thus suggested that histamine recognition by both receptors occurs via the binding of solute-binding proteins [23], an indirect mechanism for the activation of different bacterial sensor proteins that appears to be widespread among bacteria [63].

2.1.6. The Chemoreceptor TlpQ Binds Histamine at its Ligand-Binding Domain with High Affinity

In contrast to PctA and PctC, the LBD of the TlpQ chemoreceptor bound histamine directly [23]. Microcalorimetric titrations of the TlpQ sensor domain revealed a dissociation constant of $0.64 \mu \mathrm{M}$ that corresponded to an affinity significantly higher than the average for ligand recognition by chemoreceptor LBDs [64]. In addition to histamine, TlpQ also recognized structurally related polyamines, namely putrescine, cadaverine, spermidine, agmatine and ethylenediamine, with a similarly high affinity [23]. As stated above, the magnitude of histamine chemotaxis in P. putida KT2440 was inferior to that of P. aeruginosa PAO1. This finding may be related to the fact that the LBD of the McpU chemoreceptor, the TlpQ homologue in KT2440 [65], recognizes histamine with a 40-fold lower affinity [23].

Like PctA and PctC, the TlpQ chemoreceptor has a dCache type LBD, and its 3D structure in a complex with histamine has been solved by X-ray crystallography [23] (Figure 2). The TlpQ-LBD is composed of two structural $\alpha / \beta$ modules, and histamine was bound at the membrane distal module, like in the very large majority of other characterized dCache domains [59,65-68]. The molecular detail of histamine recognition by human receptors has recently been deciphered by reporting three dimensional structures of the Histamine $\mathrm{H} 1$ receptor [69] and the $\beta 3 \mathrm{GABA}_{\mathrm{A}}$ receptor in a complex with histamine [70] (Figure 2). 
A

\section{TlpQ chemoreceptor}

Pseudomonas aeruginosa

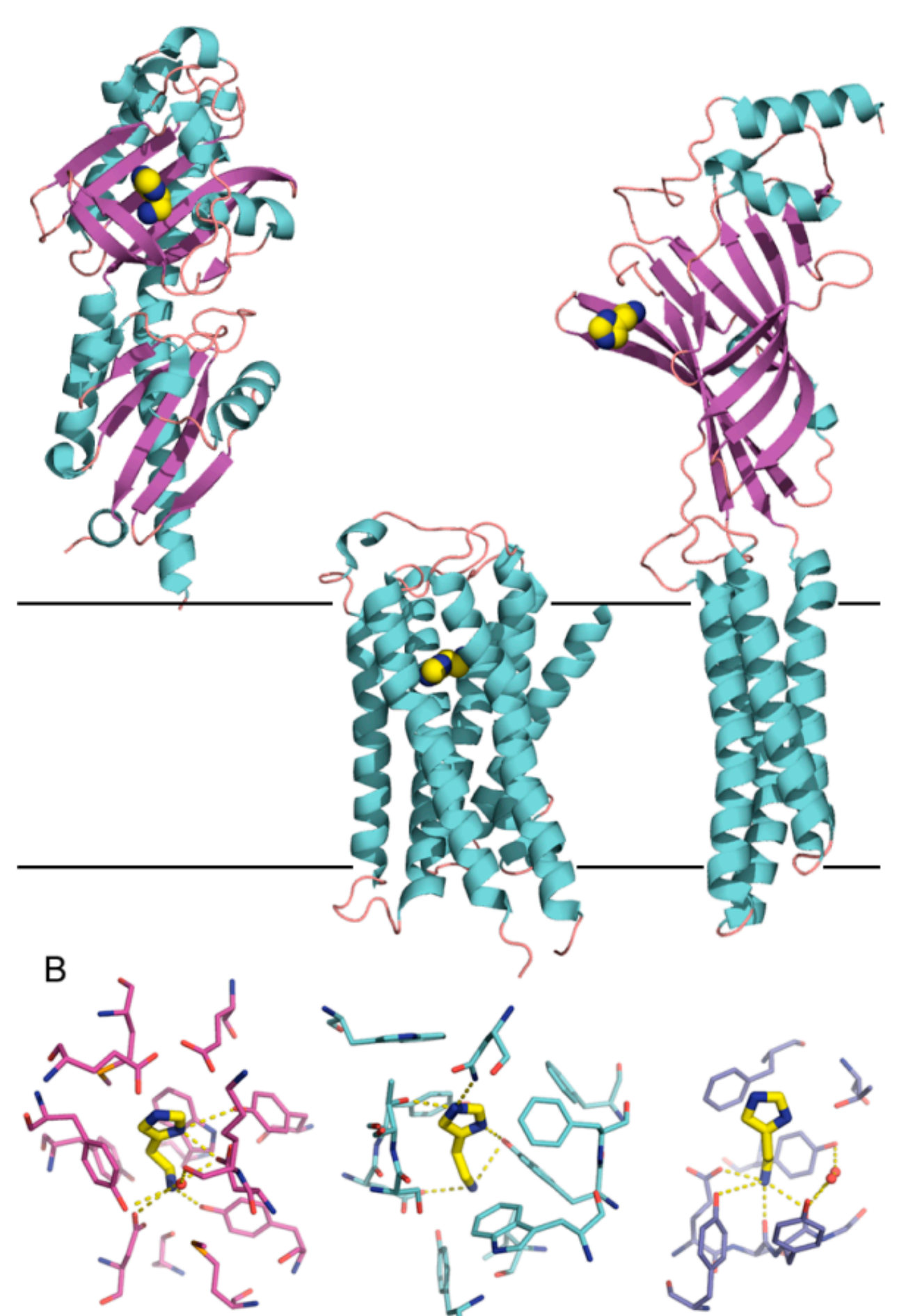

\section{Histamine $\mathrm{H} 1$ receptor}

Human $\beta 3 \mathrm{GABA}_{A}$ receptor

Human

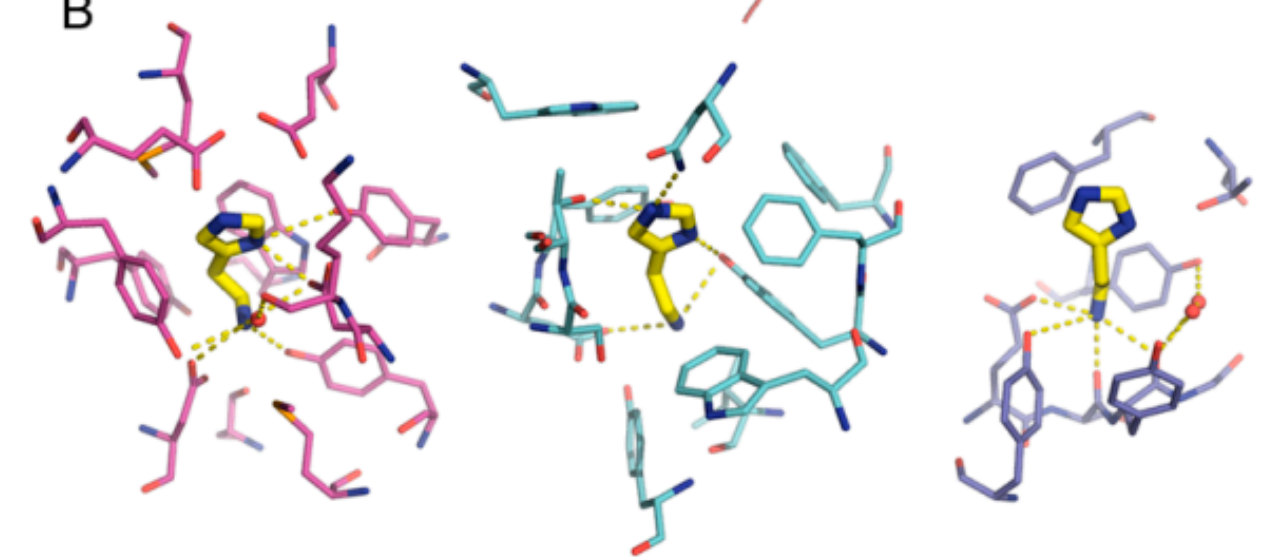

Figure 2. Bacterial and human histamine receptors. (A) Shown is the ligand-binding domain of the TlpQ chemoreceptor from P. aeruginosa PAO1 (PDB ID 6FU4), the human histamine H1 receptor (PDB ID 7DFL) and the human $\beta 3 \mathrm{GABA}_{\mathrm{A}}$ receptor (PDB ID 7A5V). Bound histamine is shown in stick mode in the lower part of the figure. These structures have been published in $[23,69,70]$. (B) Zoom on the histamine binding sites of the receptors shown above. 
The comparison of TlpQ-LBD with the two human receptors thus shows that the proteins involved in histamine sensing in bacteria and humans are entirely different. In the human $\mathrm{H} 1$ receptor, histamine is recognized within the membrane by several transmembrane helices, whereas histamine is bound to the extracytosolic part of the $\beta 3$ $\mathrm{GABA}_{\mathrm{A}}$ receptor, where it is recognized by a curved $\beta$-sheet. Although the $3 \mathrm{D}$ structures of the three histamine receptors are entirely different, there was a certain parallelism between TlpQ and the $\beta 3 G A B A_{A}$ receptor in the molecular detail of ligand recognition that is illustrated in Figure 3.

\section{TlpQ chemoreceptor}

Pseudomonas aeruginosa

\section{$\beta 3$ GABA $_{A}$ receptor}

Human

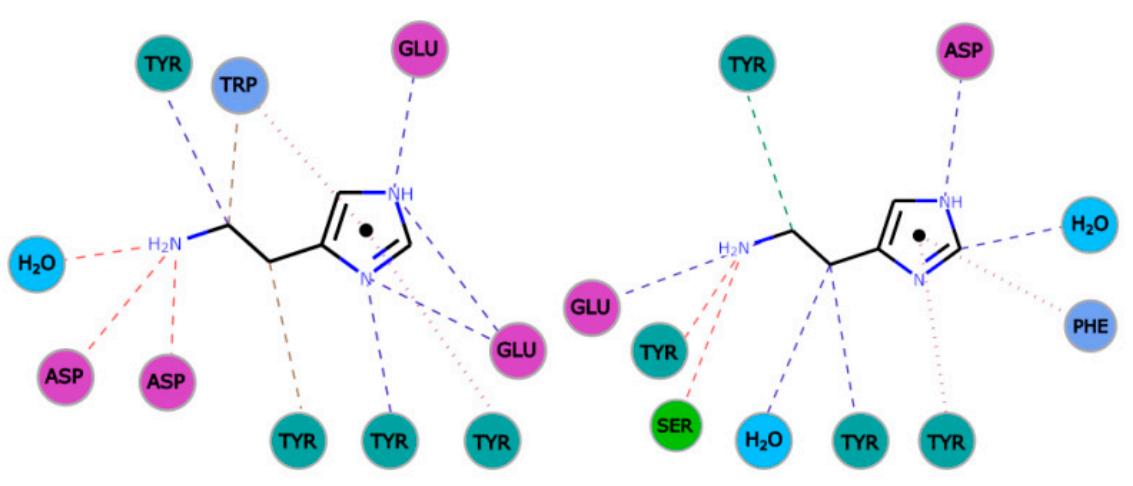

Figure 3. Parallelism in the mode of histamine recognition by P. aeruginosa TlpQ-LBD and the human $\beta 3 \mathrm{GABA}_{\mathrm{A}}$ receptor. The interaction of histamine within the different binding pocket was automatically generated at the PDBe, using Arpeggio [71]. Non-covalent interactions are shown by the following colored dashed lines: red, hydrogen bonds; green, hydrophobic interactions; brown, weak hydrogen bonds; and purple, pi-pi interactions. The thickness of each dash is related to the interaction-distance. Hydrophobic, negatively charged, aromatic and polar residues are colored in blue, magenta, green and cyan, respectively. For clarity, only some representative interactions are shown.

In both cases, the primary and secondary histamine amino groups are coordinated by negatively charged amino acids and a series of tyrosine residues that interact with the linear and cyclic parts of histamine.

\subsection{Escherichia coli}

Whereas a significant part of the transcriptional responses in P. aeruginosa appear to be related to the sensing of a histamine metabolite by the HinK transcriptional regulator, the two-component system AtoSC appears to be involved in histamine sensing in E. coli. Inspection of the sequence of the AtoS sensor kinase in Pfam [72] indicated that it has two transmembrane regions that flank a potential periplasmic sensor domain that is unannotated, but homology modeling using Phyre2 [73] indicated that it is likely to form an $\alpha / \beta$ fold, similar to an sCache domain. In addition, AtoS has a cytosolic PAS domain that may also be involved in signal sensing. On the other hand, the AtoC response regulator is a member of the NtrC-NifA family of transcriptional regulators and is composed of an $\mathrm{N}$-terminal receiver domain, followed by an AAA+_ATPase and DNA-binding domain [74]. AtoSC is encoded upstream of the atoDAEB gene cluster that encodes proteins involved in the catabolism of short chain fatty acids (SCFAs) [75], and AtoSC was found to control the expression of this operon [76,77]. SCFAs are important signal molecules in the human gut microbiome. They are produced in the colon following microbial fermentation of dietary fibers, are important energy sources for colonocytes and regulate the assembly and organization of tight junctions [78]. Abnormalities in SCFA levels, either caused by dysbiosis (i.e., alteration of gut microbiota homeostasis) or diet, were suggested to play 
a role in a number of pathologies, such as type-2 diabetes, obesity, inflammatory bowel disease, colorectal cancer or allergy [79].

The direct action of the AtoSC TCS on the expression of the atoDAEB operon also modulated the synthesis of the complexed poly-(R)-3-hydroxybutyrate (cPHB), a ubiquitous cell compound that contributes to $\mathrm{Ca}^{2+}$ homeostasis [80]. In addition, AtoSC also contributes to the regulation of flagellar gene expression and was thus shown to modulate motility and chemotaxis [81]. Spermidine and acetoacetate are the effectors of the AtoSC system [82,83]. Multiple pieces of evidence have suggested that AtoSC activity is modulated by $\mathrm{Ca}^{2+}$ that may act as a co-signal $[84,85]$. However, the molecular detail and the corresponding sensor domains of these effectors have so far not been established.

Evidence has been presented showing that histamine interferes with AtoSC activity. Histamine was shown to increase ato $\mathrm{C}$ transcription and to reduce $\mathrm{CPHB}$ biosynthesis [84,86]. cPHB biosynthesis requires SCFAs [83], and the interference of histamine with SCFA metabolism and levels may play a regulatory role in the gut. Furthermore, low concentrations of histamine enhanced motility and chemotaxis in E. coli, whereas the opposite effect was noted when histamine was present at higher levels [81]. This histaminemediated regulatory effect was not observed in a strain that contained a truncated version of AtoC that lacked the receiver domain [81]. However, the molecular mechanism by which histamine modulates AtoSC function remains unknown.

\section{Histamine Release by Bacteria and Its Consequences}

Apart from the fact that bacteria sense histamine, there is evidence that bacterialderived histamine has multiple consequences, for example, on host health [78] and food safety [87]. In fact, histamine levels are monitored in a number of different foods as a measure of food freshness $[88,89]$. This is particularly relevant for seafood products, where bacteria-secreted histamine can provoke food poisoning [87]. The list of microorganisms that secrete histamine in seafood is long and includes Gram-positive and Gram-negative species. Most abundant are Enterobacteriaceae belonging to genera such as Morganella, Enterobacter, Hafnia, Proteus and Photobacterium, as well as different pseudomonads and lactic acid bacteria of the genera Lactobacillus and Enterococcus [87].

The effect of histamine secretion by human intestinal bacteria on its host is a more recent but rapidly expanding field of research. Initial in vitro studies showed that histamine suppressed the chemokine and proinflamatory cytokine secretion in human monocytederived dendritic cells [90]. Murine studies showed that the administration of the histaminesecreting Lactobacillus rhamnosus had an anti-inflammatory effect, as evidenced by a reduction in the secretion of various interleukines and tumor necrosis factor $\alpha$. This effect was lost in animals deficient in the histamine 2 receptor, indicating that microbiota-derived histamine could be immunomodulatory [90]. Administration of another Lactobacillus species, L. saerimneri, that is able to secrete approximately 100 -fold more histamine as compared to $L$. rhamnosus, resulted, next to a variety of immune responses, in animal weight loss and signs of deteriorating health [91]. The authors suggested that the amount of histamine secreted by a microbe may be critical in determining the nature of the effect.

Another study reported that the abundance of histamine-secreting bacteria is increased in the gut of adult asthma patients. This study thus challenged the widespread concept that human mast cells and basophiles are the principal histamine sources. These data thus also suggest that bacterial-derived histamine contributes to histamine-mediated pathologies [92]. In addition, data indicting another link between bacterial-derived histamine and pathology was reported by Gallardo et al. [93]. The authors compared gut microbiota composition and metabolome in stool samples obtained from healthy children and children with diarrhea positive for diarrheagenic E. coli (DEC). Metabolomic studies revealed higher histamine concentrations in the DEC group as compared to healthy children, and altered histamine levels were associated to certain gut microbiota species such as Enterobacter hormaechei, Bifidobacterium stercoris and Shigella spp. [93]. More recent studies have suggested that bacterial histamine release in the gut does not only cause a local modulation of the host 
immune system, but can also have immunological consequences at distant mucosal sites, such as in the lung [94]. E. coli was engineered to secrete histamine and administered orally to mice [94]. The authors observed an anti-inflammatory response in the lung, as evidenced by reduced inflammatory cell numbers in bronchoalveolar lavages. Experimentation with mice deficient in the histamine 2 receptor $(\mathrm{H} 2 \mathrm{R})$ showed that the anti-inflammatory effect of bacterial-derived histamine is partially mediated by this receptor [94]. During the investigation of the impact of different metabolites produced by gut bacteria on host physiology, the effect of bacteria-produced histamine was evaluated [95]. Gut bacteria of the Morganella morganii and Lactobacillus reuteri species were found to produce histamine in vivo during the colonization of the mouse intestine, and L-His dietary supplementation increased histamine production by these bacteria. In this study, the authors found that bacteria-derived histamine was associated with increased mice colon motility and fecal output and that treatment with histamine receptor antagonists largely blocked the effect of bacterial histamine on colon motility [95].

Irritable bowel syndrome (IBS) is a common gastrointestinal disorder, and accumulating evidences at both preclinical and clinical levels indicates an involvement of enteric microbiota in its pathogenesis [96]. Histamine levels and the abundance of $h d c$ genes was determined in both healthy and IBS patients using metabolomics and metagenomics data from the integrative Human Microbiome Project. These analyses revealed that IBS patients presented higher levels of histamine and bacterial hdc genes [95]. Subsequent studies also showed that supernatants from colonic samples of IBS patients contained increased histamine levels, and expression levels of the histamine receptors H1R and H2R were upregulated in IBS patients [97]. The authors thus hypothesized that a dysbiosis with increased histamine-secreting or HDC-containing bacteria was potentially associated with the development and aggravation of IBS [96].

\section{Outlook}

The knowledge available on the role of histamine as a bacterial signal molecule is summarized in Figure 4.

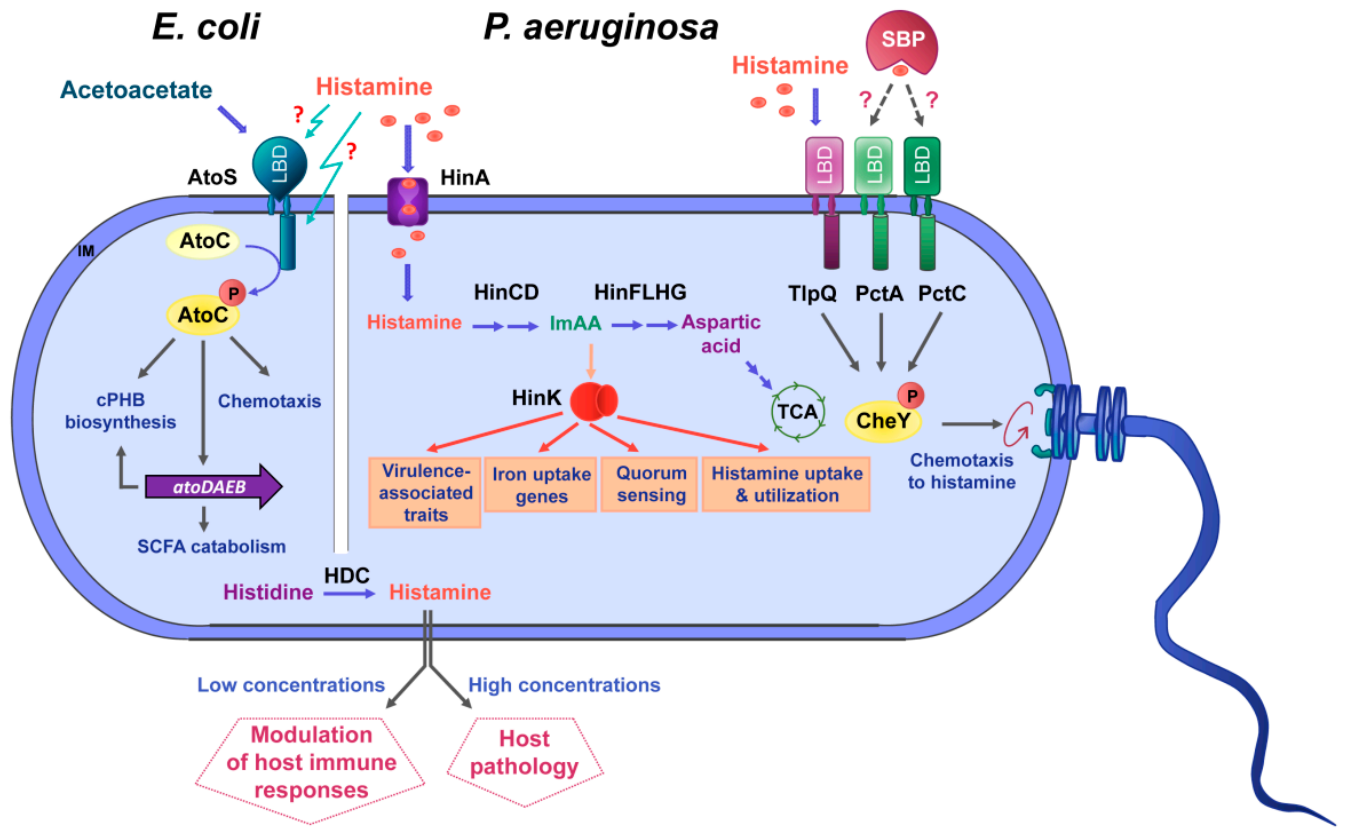

Figure 4. Summary of data available on histamine sensing and secretion by bacteria. On the left, histamine sensing by the TCS AtoSC in E. coli. On the right, histamine assimilation and chemotaxis in P. aeruginosa. Lower part: Many bacteria synthesize histamine by a decarboxylation of histidine using the histidine decarboxylase (HDC) and secrete histamine. Blue arrows: metabolic pathways; orange 
arrows: gene expression regulation; grey arrows: activation of biological processes; dotted lines: hypothetical interaction; LBD: ligand-binding domain; SBP: solute-binding protein; ImAA: imidazole4-acetic acid; HinA: permease for the histamine uptake; HinCD: enzymes for the conversion of histamine to ImAA; HinFLHG: enzymes for the conversion of ImAA to aspartic acid; HinK: LysRfamily response regulator; IM: inner membrane.

The elucidation of the role of histamine as a signal molecule for inter-domain communication is an emerging field of research that requires future efforts. So far, the information on histamine sensing is restricted to P. aeruginosa, P. putida and E. coli, and studies need to be conducted to determine to which extent other species show similar responses. The main physiological roles of chemotaxis are gaining access to compounds that serve for growth, the perception of information on the environmental niche or the localization of sites that are suitable for attachment or invasion. For key signal molecules that are of metabolic value, like histamine, it has to be determined whether the primary motivation of chemotaxis is related to metabolism or the capacity to infect hosts. There is initial evidence that bacterial histamine secretion in the gut microbiome is associated with digestive disorders. In this context, important gaps in knowledge to be closed are the determination of environmental factors that may trigger histamine release and to determine the capacity of histamine release for strains typically found in the gut microbiome. Such information would facilitate the diagnosis of histamine-related disorders from the composition of the patients' microbiome.

Author Contributions: T.K., J.A.G., F.V., M.F., A.R., E.M.-C., M.A.M.: writing-original draft preparation; T.K., M.A.M.: writing-review and editing; J.A.G., E.M.-C.: visualization; T.K., J.A.G., A.R. and M.A.M.: funding acquisition. All authors have read and agreed to the published version of the manuscript.

Funding: This work was supported by FEDER funds and the Fondo Social Europeo through grants from the CSIC to M.A.M. (PIE-202040I003), the Spanish Ministry for Science, Innovation and Universities to M.A.M. (PID2019-103972GA-I00), the Junta de Andalucía to T.K. (P18-FR-1621) and Spanish Ministry of Economy and Competitiveness (BIO2016-76779-P to T.K. and BIO2016-74875-P to J.A.G.). A.R. was supported by the Spanish Ministry of Science and Innovation, Promotion of Talent and its Employability-Ramon y Cajal R\&D\&i Programme (RYC2019-026481-I).

Conflicts of Interest: The authors do not declare any conflicts of interest.

$\begin{array}{ll}\text { Abbreviations } \\ \text { cPHB } & \text { poly-(R)-3-hydroxybutyrate } \\ \text { DEC } & \text { diarrheagenic E. coli } \\ \text { ECF } & \text { extracytoplasmic function } \\ \text { HDC } & \text { histidine decarboxylase } \\ \text { IAA } & \text { indole-3-acetic acid } \\ \text { IBS } & \text { Irritable bowel syndrome } \\ \text { ImAA } & \text { imidazole-4-acetic acid } \\ \text { LBD } & \text { ligand binding domain } \\ \text { PQS } & \text { Pseudomonas quinolone signal } \\ \text { TCS } & \text { two-component system }\end{array}$

\section{References}

1. Galperin, M.Y. What bacteria want. Environ. Microbiol. 2018, 20, 4221-4229. [CrossRef] [PubMed]

2. Krell, T.; Lacal, J.; Busch, A.; Silva-Jimenez, H.; Guazzaroni, M.E.; Ramos, J.L. Bacterial sensor kinases: Diversity in the recognition of environmental signals. Annu. Rev. Microbiol. 2010, 64, 539-559. [CrossRef] [PubMed]

3. Ortega, A.; Zhulin, I.B.; Krell, T. Sensory Repertoire of Bacterial Chemoreceptors. Microbiol. Mol. Biol. Rev. 2017, 81, e00033-17. [CrossRef] [PubMed]

4. Rosier, A.; Bishnoi, U.; Lakshmanan, V.; Sherrier, D.J.; Bais, H.P. A perspective on inter-kingdom signaling in plant-beneficial microbe interactions. Plant Mol. Biol. 2016, 90, 537-548. [CrossRef] [PubMed] 
5. McFall-Ngai, M.; Hadfield, M.G.; Bosch, T.C.; Carey, H.V.; Domazet-Loso, T.; Douglas, A.E.; Dubilier, N.; Eberl, G.; Fukami, T.; Gilbert, S.F.; et al. Animals in a bacterial world, a new imperative for the life sciences. Proc. Natl. Acad. Sci. USA 2013, 110, 3229-3236. [CrossRef] [PubMed]

6. Casanova-Saez, R.; Mateo-Bonmati, E.; Ljung, K. Auxin Metabolism in Plants. Cold Spring Harb. Perspect Biol. 2021, 13. [CrossRef]

7. Matilla, M.A.; Daddaoua, A.; Chini, A.; Morel, B.; Krell, T. An auxin controls bacterial antibiotics production. Nucleic Acids Res. 2018, 46, 11229-11238. [CrossRef]

8. Kunkel, B.N.; Johnson, J.M.B. Auxin Plays Multiple Roles during Plant-Pathogen Interactions. Cold Spring Harb. Perspect Biol. 2021. [CrossRef]

9. Li, Q.; Ren, Y.; Fu, X. Inter-kingdom signaling between gut microbiota and their host. Cell. Mol. Life Sci. 2019, 76, 2383-2389. [CrossRef]

10. Shahid, M.; Tripathi, T.; Sobia, F.; Moin, S.; Siddiqui, M.; Khan, R.A. Histamine, Histamine Receptors, and their Role in Immunomodulation: An Updated Systematic Review. Open Immunol. J. 2009, 2, 9-41. [CrossRef]

11. Patel, R.H.; Mohiuddin, S.S. Biochemistry, Histamine. In StatPearls; StatPearls Publishing: Treasure Island, FL, USA, 2021.

12. Landete, J.M.; De las Rivas, B.; Marcobal, A.; Munoz, R. Updated molecular knowledge about histamine biosynthesis by bacteria. Crit. Rev. Food Sci. Nutr. 2008, 48, 697-714. [CrossRef]

13. Bjornsdottir-Butler, K.; May, S.; Hayes, M.; Abraham, A.; Benner, R.A., Jr. Characterization of a novel enzyme from Photobacterium phosphoreum with histidine decarboxylase activity. Int. J. Food Microbiol. 2020, 334, 108815. [CrossRef] [PubMed]

14. Landete, J.M.; Pardo, I.; Ferrer, S. Histamine, histidine, and growth-phase mediated regulation of the histidine decarboxylase gene in lactic acid bacteria isolated from wine. FEMS Microbiol. Lett. 2006, 260, 84-90. [CrossRef]

15. Ferrario, C.; Borgo, F.; de Las Rivas, B.; Munoz, R.; Ricci, G.; Fortina, M.G. Sequencing, characterization, and gene expression analysis of the histidine decarboxylase gene cluster of Morganella morganii. Curr. Microbiol. 2014, 68, 404-411. [CrossRef]

16. Diaz, M.; Del Rio, B.; Ladero, V.; Redruello, B.; Fernandez, M.; Martin, M.C.; Alvarez, M.A. Histamine production in Lactobacillus vaginalis improves cell survival at low $\mathrm{pH}$ by counteracting the acidification of the cytosol. Int. J. Food Microbiol. 2020, 321, 108548. [CrossRef] [PubMed]

17. Ramos, J.L.; Timmis, K.N. Experimental evolution of catabolic pathways of bacteria. Microbiol. Sci. 1987, 4, 228-237. [PubMed]

18. De la Torre, M.; Gomez-Botran, J.L.; Olivera, E.R.; Bermejo, F.; Rodriguez-Moran, J.; Luengo, J.M. Histamine catabolism in Pseudomonas putida U: Identification of the genes, catabolic enzymes and regulators. Environ. Microbiol. 2018, 20, $1828-1841$. [CrossRef] [PubMed]

19. Iglewski, B.H. Chapter 27 Pseudomonas. In Medical Microbiology, 4th ed.; Baron, S., Ed.; University of Texas Medical Branch at Galveston: Galveston, TX, USA, 1996.

20. Juhas, M. Pseudomonas aeruginosa essentials: An update on investigation of essential genes. Microbiology 2015, 161, 2053-2060. [CrossRef] [PubMed]

21. Horino, T.; Chiba, A.; Kawano, S.; Kato, T.; Sato, F.; Maruyama, Y.; Nakazawa, Y.; Yoshikawa, K.; Yoshida, M.; Hori, S. Clinical characteristics and risk factors for mortality in patients with bacteremia caused by Pseudomonas aeruginosa. Intern. Med. 2012, 51, 59-64. [CrossRef] [PubMed]

22. WHO. Global priority list of antibiotic-resistant bacteria to guide research, discovery, and development of new antibiotics. 2017. Available online: http:/ / www.who.int/medicines/publications/global-priority-list-antibiotic-resistant-bacteria/en/ (accessed on 1 June 2021).

23. Corral-Lugo, A.; Matilla, M.A.; Martin-Mora, D.; Silva Jimenez, H.; Mesa Torres, N.; Kato, J.; Hida, A.; Oku, S.; Conejero-Muriel, M.; Gavira, J.A.; et al. High-Affinity Chemotaxis to Histamine Mediated by the TlpQ Chemoreceptor of the Human Pathogen Pseudomonas aeruginosa. mBio 2018, 9, e01894-18. [CrossRef] [PubMed]

24. Wang, Y.; Cao, Q.; Cao, Q.; Gan, J.; Sun, N.; Yang, C.-G.; Bae, T.; Wuh, M.; Lan, L. Histamine activates HinK to promote the virulence of Pseudomonas aeruginosa. Sci. Bull. 2021, 66, 1101-1118. [CrossRef]

25. Ghysels, B.; Ochsner, U.; Mollman, U.; Heinisch, L.; Vasil, M.; Cornelis, P.; Matthijs, S. The Pseudomonas aeruginosa pirA gene encodes a second receptor for ferrienterobactin and synthetic catecholate analogues. FEMS Microbiol. Lett. 2005, 246, 167-174. [CrossRef] [PubMed]

26. Guillon, L.; Altenburger, S.; Graumann, P.L.; Schalk, I.J. Deciphering protein dynamics of the siderophore pyoverdine pathway in Pseudomonas aeruginosa. PloS ONE 2013, 8, e79111. [CrossRef]

27. Llamas, M.A.; Sparrius, M.; Kloet, R.; Jimenez, C.R.; Vandenbroucke-Grauls, C.; Bitter, W. The heterologous siderophores ferrioxamine B and ferrichrome activate signaling pathways in Pseudomonas aeruginosa. J. Bacteriol. 2006, 188, $1882-1891$. [CrossRef] [PubMed]

28. Bastiaansen, K.C.; van Ulsen, P.; Wijtmans, M.; Bitter, W.; Llamas, M.A. Self-cleavage of the Pseudomonas aeruginosa Cell-surface Signaling Anti-sigma Factor FoxR Occurs through an N-O Acyl Rearrangement. J. Biol. Chem. 2015, 290, 12237-12246. [CrossRef] [PubMed]

29. Otero-Asman, J.R.; Garcia-Garcia, A.I.; Civantos, C.; Quesada, J.M.; Llamas, M.A. Pseudomonas aeruginosa possesses three distinct systems for sensing and using the host molecule haem. Environ. Microbiol. 2019, 21, 4629-4647. [CrossRef] [PubMed]

30. Ghysels, B.; Dieu, B.T.M.; Beatson, S.A.; Pirnay, J.P.; Ochsner, U.A.; Vasil, M.L.; Cornelis, P. FpvB, an alternative type I ferripyoverdine receptor of Pseudomonas aeruginosa. Microbiology (Reading) 2004, 150, 1671-1680. [CrossRef] 
31. Cunrath, O.; Gasser, V.; Hoegy, F.; Reimmann, C.; Guillon, L.; Schalk, I.J. A cell biological view of the siderophore pyochelin iron uptake pathway in Pseudomonas aeruginosa. Environ. Microbiol. 2015, 17, 171-185. [CrossRef]

32. Adhikari, P.; Kirby, S.D.; Nowalk, A.J.; Veraldi, K.L.; Schryvers, A.B.; Mietzner, T.A. Biochemical characterization of a Haemophilus influenzae periplasmic iron transport operon. J. Biol. Chem. 1995, 270, 25142-25149. [CrossRef]

33. Garcia-Reyes, S.; Soberon-Chavez, G.; Cocotl-Yanez, M. The third quorum-sensing system of Pseudomonas aeruginosa: Pseudomonas quinolone signal and the enigmatic PqsE protein. J. Med. Microbiol. 2020, 69, 25-34. [CrossRef]

34. Gallagher, L.A.; McKnight, S.L.; Kuznetsova, M.S.; Pesci, E.C.; Manoil, C. Functions required for extracellular quinolone signaling by Pseudomonas aeruginosa. J. Bacteriol. 2002, 184, 6472-6480. [CrossRef] [PubMed]

35. Quinaud, M.; Chabert, J.; Faudry, E.; Neumann, E.; Lemaire, D.; Pastor, A.; Elsen, S.; Dessen, A.; Attree, I. The PscE-PscF-PscG complex controls type III secretion needle biogenesis in Pseudomonas aeruginosa. J. Biol. Chem. 2005, 280, 36293-36300. [CrossRef] [PubMed]

36. Wozniak, D.J.; Cram, D.C.; Daniels, C.J.; Galloway, D.R. Nucleotide sequence and characterization of toxR: A gene involved in exotoxin A regulation in Pseudomonas aeruginosa. Nucleic Acids Res. 1987, 15, 2123-2135. [CrossRef] [PubMed]

37. Wu, W.; Jin, S. PtrB of Pseudomonas aeruginosa suppresses the type III secretion system under the stress of DNA damage. J. Bacteriol. 2005, 187, 6058-6068. [CrossRef] [PubMed]

38. Rampioni, G.; Schuster, M.; Greenberg, E.P.; Zennaro, E.; Leoni, L. Contribution of the RsaL global regulator to Pseudomonas aeruginosa virulence and biofilm formation. FEMS Microbiol. Lett. 2009, 301, 210-217. [CrossRef]

39. Dong, Y.H.; Zhang, X.F.; Xu, J.L.; Tan, A.T.; Zhang, L.H. VqsM, a novel AraC-type global regulator of quorum-sensing signalling and virulence in Pseudomonas aeruginosa. Mol. Microbiol. 2005, 58, 552-564. [CrossRef]

40. Dean, C.R.; Neshat, S.; Poole, K. PfeR, an enterobactin-responsive activator of ferric enterobactin receptor gene expression in Pseudomonas aeruginosa. J. Bacteriol. 1996, 178, 5361-5369. [CrossRef]

41. Shen, D.K.; Filopon, D.; Kuhn, L.; Polack, B.; Toussaint, B. PsrA is a positive transcriptional regulator of the type III secretion system in Pseudomonas aeruginosa. Infect. Immun. 2006, 74, 1121-1129. [CrossRef]

42. Williams McMackin, E.A.; Marsden, A.E.; Yahr, T.L. H-NS Family Members MvaT and MvaU Regulate the Pseudomonas aeruginosa Type III Secretion System. J. Bacteriol. 2019, 201. [CrossRef]

43. Alford, M.A.; Baghela, A.; Yeung, A.T.Y.; Pletzer, D.; Hancock, R.E.W. NtrBC Regulates Invasiveness and Virulence of Pseudomonas aeruginosa During High-Density Infection. Front. Microbiol. 2020, 11, 773. [CrossRef]

44. Zeng, B.; Wang, C.; Zhang, P.; Guo, Z.; Chen, L.; Duan, K. Heat Shock Protein DnaJ in Pseudomonas aeruginosa Affects Biofilm Formation via Pyocyanin Production. Microorganisms 2020, 8, 395. [CrossRef]

45. Okuda, J.; Yamane, S.; Nagata, S.; Kunikata, C.; Suezawa, C.; Yasuda, M. The Pseudomonas aeruginosa dnaK gene is involved in bacterial translocation across the intestinal epithelial cell barrier. Microbiology (Reading) 2017, 163, 1208-1216. [CrossRef]

46. Matilla, M.A.; Martin-Mora, D.; Gavira, J.A.; Krell, T. Pseudomonas aeruginosa as a Model To Study Chemosensory Pathway Signaling. Microbiol. Mol. Biol. Rev. 2021, 85. [CrossRef] [PubMed]

47. Garvis, S.; Munder, A.; Ball, G.; de Bentzmann, S.; Wiehlmann, L.; Ewbank, J.J.; Tummler, B.; Filloux, A. Caenorhabditis elegans semi-automated liquid screen reveals a specialized role for the chemotaxis gene cheB2 in Pseudomonas aeruginosa virulence. PLoS Pathog. 2009, 5, e1000540. [CrossRef]

48. Dong, Y.H.; Zhang, X.F.; Soo, H.M.; Greenberg, E.P.; Zhang, L.H. The two-component response regulator PprB modulates quorum-sensing signal production and global gene expression in Pseudomonas aeruginosa. Mol. Microbiol. 2005, 56, $1287-1301$. [CrossRef]

49. Bardy, S.L.; Maddock, J.R. Polar localization of a soluble methyl-accepting protein of Pseudomonas aeruginosa. J. Bacteriol. 2005, 187, 7840-7844. [CrossRef] [PubMed]

50. Rico-Jimenez, M.; Reyes-Darias, J.A.; Ortega, A.; Diez Pena, A.I.; Morel, B.; Krell, T. Two different mechanisms mediate chemotaxis to inorganic phosphate in Pseudomonas aeruginosa. Sci. Rep. 2016, 6, 28967. [CrossRef] [PubMed]

51. Zaborin, A.; Romanowski, K.; Gerdes, S.; Holbrook, C.; Lepine, F.; Long, J.; Poroyko, V.; Diggle, S.P.; Wilke, A.; Righetti, K.; et al. Red death in Caenorhabditis elegans caused by Pseudomonas aeruginosa PAO1. Proc. Natl. Acad. Sci. USA 2009, 106, 6327-6332. [CrossRef] [PubMed]

52. De Bentzmann, S.; Aurouze, M.; Ball, G.; Filloux, A. FppA, a novel Pseudomonas aeruginosa prepilin peptidase involved in assembly of type IVb pili. J. Bacteriol. 2006, 188, 4851-4860. [CrossRef]

53. Lee, J.S.; Heo, Y.J.; Lee, J.K.; Cho, Y.H. KatA, the major catalase, is critical for osmoprotection and virulence in Pseudomonas aeruginosa PA14. Infect. Immun. 2005, 73, 4399-4403. [CrossRef]

54. Scheepers, G.H.; Lycklama, A.N.J.A.; Poolman, B. An updated structural classification of substrate-binding proteins. FEBS. Lett. 2016, 590, 4393-4401. [CrossRef] [PubMed]

55. Fernandez, M.; Rico-Jimenez, M.; Ortega, A.; Daddaoua, A.; Garcia Garcia, A.I.; Martin-Mora, D.; Torres, N.M.; Tajuelo, A.; Matilla, M.A.; Krell, T. Determination of Ligand Profiles for Pseudomonas aeruginosa Solute Binding Proteins. Int. J. Mol. Sci. 2019, 20, 5156. [CrossRef]

56. Ortega, D.R.; Fleetwood, A.D.; Krell, T.; Harwood, C.S.; Jensen, G.J.; Zhulin, I.B. Assigning chemoreceptors to chemosensory pathways in Pseudomonas aeruginosa. Proc. Natl. Acad. Sci. USA 2017, 114, 12809-12814. [CrossRef]

57. Wu, H.; Kato, J.; Kuroda, A.; Ikeda, T.; Takiguchi, N.; Ohtake, H. Identification and characterization of two chemotactic transducers for inorganic phosphate in Pseudomonas aeruginosa. J. Bacteriol. 2000, 182, 3400-3404. [CrossRef] [PubMed] 
58. Bains, M.; Fernandez, L.; Hancock, R.E. Phosphate starvation promotes swarming motility and cytotoxicity of Pseudomonas aeruginosa. Appl. Environ. Microbiol. 2012, 78, 6762-6768. [CrossRef] [PubMed]

59. Gavira, J.A.; Gumerov, V.M.; Rico-Jimenez, M.; Petukh, M.; Upadhyay, A.A.; Ortega, A.; Matilla, M.A.; Zhulin, I.B.; Krell, T. How Bacterial Chemoreceptors Evolve Novel Ligand Specificities. mBio 2020, 11, e03066-19. [CrossRef]

60. Rico-Jimenez, M.; Munoz-Martinez, F.; Garcia-Fontana, C.; Fernandez, M.; Morel, B.; Ortega, A.; Ramos, J.L.; Krell, T. Paralogous chemoreceptors mediate chemotaxis towards protein amino acids and the non-protein amino acid gamma-aminobutyrate (GABA). Mol. Microbiol. 2013, 88, 1230-1243. [CrossRef] [PubMed]

61. Taguchi, K.; Fukutomi, H.; Kuroda, A.; Kato, J.; Ohtake, H. Genetic identification of chemotactic transducers for amino acids in Pseudomonas aeruginosa. Microbiology 1997, 143 (Pt 10), 3223-3229. [CrossRef]

62. Upadhyay, A.A.; Fleetwood, A.D.; Adebali, O.; Finn, R.D.; Zhulin, I.B. Cache Domains That are Homologous to, but Different from PAS Domains Comprise the Largest Superfamily of Extracellular Sensors in Prokaryotes. PLoS Comput. Biol. 2016, 12, e1004862. [CrossRef]

63. Matilla, M.A.; Ortega, A.; Krell, T. The role of solute binding proteins in signal transduction. Comput. Struct. Biotechnol. J. 2021, 19, 1786-1805. [CrossRef]

64. Matilla, M.A.; Mora, D.M.; Krell, T. The use of Isothermal Titration Calorimetry to unravel chemotactic signaling mechanisms. Environ. Microbiol. 2020, 22, 3005-3019. [CrossRef] [PubMed]

65. Gavira, J.A.; Ortega, A.; Martin-Mora, D.; Conejero-Muriel, M.T.; Corral-Lugo, A.; Morel, B.; Matilla, M.A.; Krell, T. Structural Basis for Polyamine Binding at the dCACHE Domain of the McpU Chemoreceptor from Pseudomonas putida. J. Mol. Biol. 2018, 430, 1950-1963. [CrossRef] [PubMed]

66. Shrestha, M.; Compton, K.K.; Mancl, J.M.; Webb, B.A.; Brown, A.M.; Scharf, B.E.; Schubot, F.D. Structure of the sensory domain of McpX from Sinorhizobium meliloti, the first known bacterial chemotactic sensor for quaternary ammonium compounds. Biochem. J. 2018, 475, 3949-3962. [CrossRef]

67. Nishiyama, S.; Takahashi, Y.; Yamamoto, K.; Suzuki, D.; Itoh, Y.; Sumita, K.; Uchida, Y.; Homma, M.; Imada, K.; Kawagishi, I. Identification of a Vibrio cholerae chemoreceptor that senses taurine and amino acids as attractants. Sci. Rep. 2016, 6, 20866. [CrossRef]

68. Khan, M.F.; Machuca, M.A.; Rahman, M.M.; Koc, C.; Norton, R.S.; Smith, B.J.; Roujeinikova, A. Structure-Activity Relationship Study Reveals the Molecular Basis for Specific Sensing of Hydrophobic Amino Acids by the Campylobacter jejuni Chemoreceptor Tlp3. Biomolecules 2020, 10, 744. [CrossRef]

69. Xia, R.; Wang, N.; Xu, Z.; Lu, Y.; Song, J.; Zhang, A.; Guo, C.; He, Y. Cryo-EM structure of the human histamine H1 receptor/Gq complex. Nat. Comm. 2021, 12, 2086. [CrossRef] [PubMed]

70. Nakane, T.; Kotecha, A.; Sente, A.; McMullan, G.; Masiulis, S.; Brown, P.; Grigoras, I.T.; Malinauskaite, L.; Malinauskas, T.; Miehling, J.; et al. Single-particle cryo-EM at atomic resolution. Nature 2020, 587, 152-156. [CrossRef] [PubMed]

71. Jubb, H.C.; Higueruelo, A.P.; Ochoa-Montaño, B.; Pitt, W.R.; Ascher, D.B.; Blundell, T.L. Arpeggio: A Web Server for Calculating and Visualising Interatomic Interactions in Protein Structures. J. Mol. Biol. 2017, 429, 365-371. [CrossRef]

72. Mistry, J.; Chuguransky, S.; Williams, L.; Qureshi, M.; Salazar, G.A.; Sonnhammer, E.L.L.; Tosatto, S.C.E.; Paladin, L.; Raj, S.; Richardson, L.J.; et al. Pfam: The protein families database in 2021. Nucleic Acids Res. 2021, 49, D412-D419. [CrossRef] [PubMed]

73. Kelley, L.A.; Mezulis, S.; Yates, C.M.; Wass, M.N.; Sternberg, M.J. The Phyre2 web portal for protein modeling, prediction and analysis. Nature Protoc. 2015, 10, 845-858. [CrossRef]

74. Kyriakidis, D.A.; Tiligada, E. Signal transduction and adaptive regulation through bacterial two-component systems: The Escherichia coli AtoSC paradigm. Amino Acids 2009, 37, 443-458. [CrossRef]

75. Jenkins, L.S.; Nunn, W.D. Genetic and molecular characterization of the genes involved in short-chain fatty acid degradation in Escherichia coli: The ato system. J. Bacteriol. 1987, 169, 42-52. [CrossRef] [PubMed]

76. Lioliou, E.E.; Mimitou, E.P.; Grigoroudis, A.I.; Panagiotidis, C.H.; Panagiotidis, C.A.; Kyriakidis, D.A. Phosphorylation activity of the response regulator of the two-component signal transduction system AtoS-AtoC in E. coli. Biochim. Biophys. Acta 2005, 1725, 257-268. [CrossRef]

77. Jenkins, L.S.; Nunn, W.D. Regulation of the ato operon by the atoC gene in Escherichia coli. J. Bacteriol. 1987, 169, 2096-2102. [CrossRef] [PubMed]

78. Barcik, W.; Wawrzyniak, M.; Akdis, C.A.; O’Mahony, L. Immune regulation by histamine and histamine-secreting bacteria. Curr. Opin. Immunol. 2017, 48, 108-113. [CrossRef]

79. Thorburn, A.N.; Macia, L.; Mackay, C.R. Diet, metabolites, and "western-lifestyle" inflammatory diseases. Immunity 2014, 40, 833-842. [CrossRef]

80. Theodorou, M.C.; Panagiotidis, C.A.; Panagiotidis, C.H.; Pantazaki, A.A.; Kyriakidis, D.A. Involvement of the AtoS-AtoC signal transduction system in poly-(R)-3-hydroxybutyrate biosynthesis in Escherichia coli. Biochim. Biophys. Acta 2006, 1760, 896-906. [CrossRef]

81. Theodorou, M.C.; Theodorou, E.C.; Kyriakidis, D.A. Involvement of AtoSC two-component system in Escherichia coli flagellar regulon. Amino Acids 2012, 43, 833-844. [CrossRef] [PubMed]

82. Theodorou, M.C.; Theodorou, E.C.; Panagiotidis, C.A.; Kyriakidis, D.A. Spermidine triggering effect to the signal transduction through the AtoS-AtoC/Az two-component system in Escherichia coli. Biochim. Biophys. Acta 2007, 1770, 1104-1114. [CrossRef] 
83. Theodorou, E.C.; Theodorou, M.C.; Kyriakidis, D.A. Regulation of poly-(R)-(3-hydroxybutyrate-co-3-hydroxyvalerate) biosynthesis by the AtoSCDAEB regulon in phaCAB+ Escherichia coli. Appl. Microbiol. Biotechnol. 2013, 97, 5259-5274. [CrossRef] [PubMed]

84. Theodorou, M.C.; Tiligada, E.; Kyriakidis, D.A. Extracellular Ca2+ transients affect poly-(R)-3-hydroxybutyrate regulation by the AtoS-AtoC system in Escherichia coli. Biochem. J. 2009, 417, 667-672. [CrossRef]

85. Theodorou, M.C.; Kyriakidis, D.A. Calcium channels blockers inhibit the signal transduction through the AtoSC system in Escherichia coli. Eur. J. Pharm. Sci. 2012, 47, 84-96. [CrossRef]

86. Kyriakidis, D.A.; Theodorou, M.C.; Filippou, P.S.; Kyriakidis, K.D.; Tiligada, E. Effect of histamine on the signal transduction of the AtoS-AtoC two component system and involvement in poly-(R)-3-hydroxybutyrate biosynthesis in Escherichia coli. Amino Acids 2008, 35, 45-52. [CrossRef] [PubMed]

87. Visciano, P.; Schirone, M.; Paparella, A. An Overview of Histamine and Other Biogenic Amines in Fish and Fish Products. Foods 2020, 9, 1795. [CrossRef] [PubMed]

88. Moniente, M.; Garcia-Gonzalo, D.; Ontanon, I.; Pagan, R.; Botello-Morte, L. Histamine accumulation in dairy products: Microbial causes, techniques for the detection of histamine-producing microbiota, and potential solutions. Compr. Rev. Food Sci. Food Saf. 2021, 20, 1481-1523. [CrossRef]

89. Rossi, F.; Gardini, F.; Rizzotti, L.; La Gioia, F.; Tabanelli, G.; Torriani, S. Quantitative analysis of histidine decarboxylase gene (hdcA) transcription and histamine production by Streptococcus thermophilus PRI60 under conditions relevant to cheese making. Appl. Environ. Microbiol. 2011, 77, 2817-2822. [CrossRef] [PubMed]

90. Frei, R.; Ferstl, R.; Konieczna, P.; Ziegler, M.; Simon, T.; Rugeles, T.M.; Mailand, S.; Watanabe, T.; Lauener, R.; Akdis, C.A.; et al. Histamine receptor 2 modifies dendritic cell responses to microbial ligands. J. Allergy Clin. Immunol. 2013, 132, 194-204. [CrossRef] [PubMed]

91. Ferstl, R.; Frei, R.; Schiavi, E.; Konieczna, P.; Barcik, W.; Ziegler, M.; Lauener, R.P.; Chassard, C.; Lacroix, C.; Akdis, C.A.; et al. Histamine receptor 2 is a key influence in immune responses to intestinal histamine-secreting microbes. J. Allergy Clin. Immunol. 2014, 134, 744-746. [CrossRef]

92. Barcik, W.; Pugin, B.; Westermann, P.; Perez, N.R.; Ferstl, R.; Wawrzyniak, M.; Smolinska, S.; Jutel, M.; Hessel, E.M.; Michalovich, D.; et al. Histamine-secreting microbes are increased in the gut of adult asthma patients. J. Allergy Clin. Immunol. 2016, 138, 1491-1494 e1497. [CrossRef] [PubMed]

93. Gallardo, P.; Izquierdo, M.; Vidal, R.M.; Soto, F.; Ossa, J.C.; Farfan, M.J. Gut Microbiota-Metabolome Changes in Children With Diarrhea by Diarrheagenic E. coli. Front. Cell Infect. Microbiol. 2020, 10, 485. [CrossRef]

94. Barcik, W.; Pugin, B.; Bresco, M.S.; Westermann, P.; Rinaldi, A.; Groeger, D.; Van Elst, D.; Sokolowska, M.; Krawczyk, K.; Frei, R.; et al. Bacterial secretion of histamine within the gut influences immune responses within the lung. Allergy 2019, 74, 899-909. [CrossRef] [PubMed]

95. Chen, H.; Nwe, P.K.; Yang, Y.; Rosen, C.E.; Bielecka, A.A.; Kuchroo, M.; Cline, G.W.; Kruse, A.C.; Ring, A.M.; Crawford, J.M.; et al. A Forward Chemical Genetic Screen Reveals Gut Microbiota Metabolites That Modulate Host Physiology. Cell 2019, 177, 1217-1231 e1218. [CrossRef] [PubMed]

96. Mishima, Y.; Ishihara, S. Molecular Mechanisms of Microbiota-Mediated Pathology in Irritable Bowel Syndrome. Int. J. Mol. Sci. 2020, 21, 8664. [CrossRef] [PubMed]

97. Barbara, G.; Wang, B.; Stanghellini, V.; de Giorgio, R.; Cremon, C.; Di Nardo, G.; Trevisani, M.; Campi, B.; Geppetti, P.; Tonini, M.; et al. Mast cell-dependent excitation of visceral-nociceptive sensory neurons in irritable bowel syndrome. Gastroenterology 2007, 132, 26-37. [CrossRef] [PubMed] 